\title{
HYGIENIC CRITERIA OF SMOKED HERRING FISH MARKETED IN KAFR EL- SHEIKH CITY
}

\author{
E. M. I. Khalifa and G.. I . Mazyad
}

"Animal Health Research Institute Kafr El-Sheikh branch Food Hygiene Unit

"Animal Health Research Institute Kafr El-Sheikh branch Bacteriology Unit

\begin{abstract}
A total number of one hundred samples from each packed and unpacked locally produced smoked herring fish (50 of each) were collected randomly from different shops and supermarkets of different sanitation levels at Kafr El-sheikh city. The collected samples were directly transferred to the laboratory under complete aseptic conditions with a minimum of delay where they were subjected to sensory, chemical and microbiological evaluation. The obtained results revealed that, regarding the sensory evaluation only $2 \%$ of packed smoked herring fish samples were rejected due to macerated skin, friable consistency and musty flesh odor. Meanwhile unpacked examined samples contained 14\% rejected due to macerated skin, very macerated skin and friable consistency, and $10 \%$ rejected due to musty flesh odor and salty flesh taste. Concerning the chemical examination, $4 \%$ of packed smoked herring fish samples were rejected due to their over $\mathrm{pH}$, value while $16 \%, 12 \%, 8 \%$ and $10 \%$ of unpacked smoked herring fish samples were rejected due to their $\mathrm{pH}$ value, TVN content, salt content and thiobarbituric acid number respectively. On the other hand, microbiologically, all the samples of packed smoked herring fish lied within the limits of Egyptian standard of smoked fish number 228/2005, concerning unpacked samples 10\%, 12\%, 20\% and $12 \%$ were rejected due to contamination with total aerobic bacterial count, total anaerobic bacterial count, total coliforms count and Staphylococcus aureus coagulase positive respectively, more than the accepted limits of the previous standard. The recommended points to safety and quality of smoked herring fish were discussed.
\end{abstract}




\section{INTRODUCTION}

Herring are small, oily fish of the genus Clupea found in the shallow, temperate waters of the North Atlantic, the Baltic sea, the North Pacific and the Mediterranean sea. There are 15 species of herring, the most abundant of which is the Atlantic herring (Clupea harengus).

Smoked fish is that fish which salted by sodium chloride and partially dried, then exposed to smoke which produced by burning of special type of wood or saw dust, the smoke must penetrate the meat tissue to give the final product special color, taste and odor (Egyptian standard specification of smoked fish 288/2005) .

Smoking is a very old preservation process, and still widely used in many countries to impart the characteristic desirable smoke flavor and golden color for smoked fish by the action of volatile phenolic compounds, carbonyls and acids of smoke $(\boldsymbol{F A O}, 1970)$. Smoked fish is a popular type of fish products that have been consumed on a large scale in Egypt, particularly at picnics and some occasions as "Sham El-Neseem". Imported frozen herring(Clupea harengus)is the most common fish used for smoking.

Man has used smoke for preservation and preparation of food for thousands of years (Krasemann, 2004). Several methods are available for smoking and different smoked products have been developed in various parts of the world in relation to the properties of the locally available raw materials and general level of technology (Olley et al. 1988). The process of smoking includes different preservative steps such as salting, drying and smoking. 
Herring is a kind of smoked fish which may be held in brine and freshened prior to smoking. Herring is subjected to many risks of either primary or secondary contamination. Such contaminations may render the smoked fish unfit for human consumption or even harmful to consumers (Van Den Broek et al. 1984).

Smoked herring fish are usually eaten as seasonal diet among Egyptian allover the year particularly in the eastern feast (Sham ElNessem). In the particular season emergency measures were taken every where allover the country to prevent and to treat a possible due to the consumption of anomalous amount of the product in that particular feast day. Moreover talks and discussion of it are held annually just before and during this season about possible risk coming due to the consumption of smoked fish. Cases are recorded every year due to poisoning with some deaths of admonish importance of this direction of the botulism and the staphylococcal intoxication.

The aim of the work: Much has been reported on the microbiological examination of fresh fish at Kafr EL- Sheikh city. However, no real attempts has been recorded to the hygienic status of smoked herring fish. So the goal of this study is to evaluate the sensory, chemical and microbiological conditions of packed and unpacked smoked herring fish sold at Kafr EL- Sheikh city.

\section{MATERIAL AND METHODS}

\section{1- MATERIAL:}

A total number of one hundred samples from packed and unpacked smoked herring fish (50 of each) were collected randomly from different shops and supermarkets of different sanitation levels at Kafr El-Sheikh 
city. The collected samples were directly transferred to the laboratory under complete aseptic conditions with a minimum of delay where they were subjected to sensory, chemical and microbiological examination .

\section{2- METHODS:}

\subsection{Sensory examination:}

Sensory examination of smoked herring fish (packed and unpacked samples) were evaluated for skin condition, consistency, color and odor of fish flesh according to Conell (1990).

\subsection{Chemical examination:}

2.2.1 Measurement of $\mathbf{p H}$ value: Was carried out according to the technique recommended by ISO (1979).

2.2.2 Determination of total volatile bases nitrogen (TVB-N): Was performed according to the technique recommended by $\boldsymbol{F A O}(\mathbf{1 9 8 0})$.

2.2.3 Salt determination: Was done according to the technique recommended by $A O A C$ (1990).

2.2.4 Determination of thiobarbituric acid number: Was measured according to the technique recommended by Tarladgis et al. (1960) with modification of Pikul et al. (1983).

\subsection{Microbiological examination:}

2.3.1 Preparation of samples: The samples were prepared according to the technique adopted by ICMSF (1978).

2.3.2 Total colony count: It was carried out as recommended by ICMSF. (1996). 
Hygienic Criteria Of Smoked Herring Fish Marketed ...

2.3.3 Determination of total anaerobic count: The count was carried out according to ICMSF (1996).

2.3.4 Total mould and yeast count: It was carried out as recommended by Baily and Scott (1998).

2.3.5 Total Coliforms count (MPN/g): It was carried out as recommended by ICMSF (1978).

2.3.6 Total Bacillus cereus count: It was carried out as recommended by ICMSF (1978).

2.3.7 Total Staphylococcus aureus count: It was carried out as recommended by $\boldsymbol{F A O}$ (1992), The suspected colonies were subjected to coagulase test.

2.3.8 Enumeration of presumptive Escherichia coli : It was carried out according to $I S O$ (1994) - 11866.

2.3.9 Determination of Vibrio Paraheamolyticus: It was carried out according to $\boldsymbol{A P H A}$ (1992).

2.3.9 Detection and determination of Listeria monocytogenes: It was carried out according to ISO (1995) - 11290.

2.3.10 Detection of Salmonellae: It was carried out according to Monica (1984) and Finegold and JoBaron (1986).

2.3.11 Detection of Clostridium botulinum: It was carried out according to Thatcher and Clark, (1968). 


\section{RESULTS AND DISCUSSION}

The organoleptic quality of smoked fish received the attention of some insiders in the EC community (Howgate et al. 1992). The early work made by (Shewan et al. 1956) and that reported by (Wheaton and Lawson 1985, Conell 1995 and Ruiter 1995) enable rates of spoilage to be measured in sensory terms and make more precise comparison as well as multilingual guide to freshness grades. Ideally smoked fish should get its flavor and mahogany color from the smoke.

The achieved results in table (1) revealed that, the sensory examination of packed smoked herring fish for skin condition indicated that $98 \%$ of packed smoked herring were with accepted intact skin and $2 \%$ were with unaccepted macerated skin while $88 \%$ of unpacked samples were with accepted intact skin, $10 \%$ had macerated skin and $2 \%$ very macerated skin and this may be attributed to using imported frozen herring fish, which could be macerated during splitting and thawing of fish block, or due to physical damage. Also examination of packed and unpacked smoked herring fish for skin color condition indicated that, $10 \%$ and $6 \%$ of samples were with golden brown color respectively meanwhile, $90 \%$ and $94 \%$ of samples were with golden yellow color respectively and no sample was recorded with dark brown or mouldy growth which indicate complete and good smoking processes. On the other hand, concerning consistency condition indicated that, $98 \%$ and $86 \%$ of samples were firm respectively, and $2 \%$ and $14 \%$ of sample were friable respectively, and this could be attributed to high fat content or the beginning of deterioration but no samples were soft or dry, also examination of packed and unpacked herring for flesh odor condition indicated that, $98 \%$ and $90 \%$ of samples were considered as smoked 
fishy odor respectively, and $2 \%$ and $14 \%$ of sample were musty odor respectively, and this may be attributed to the beginning of deterioration. Also examination for flesh taste condition indicated that all the packed samples were with smoked fishy taste but the unpacked smoked herring fish indicated that $90 \%$ were with smoked fishy taste and $10 \%$ were with salty taste and this may be attributed to over use brine solution, meanwhile, no sample from packed and unpacked smoked herring fish were with bitter or musty taste. Nearly similar findings were obtained by (Bastaworows et al. 2000) and (El-Kewaiely 2001). (Egyptian standard of smoked fish 228/2005) stated that, $\mathrm{pH}$ value of smoked fish should be less than 6.8, total volatile base nitrogen not more than $35 \mathrm{mg} / 100 \mathrm{~g}$., salt content not more than $2 \%$ and thiobarbituric acid not more than 4.5 mg malonaldehyde / Kg.

$\mathrm{pH}$ is among the most critical factors affecting microbial growth and spoilage of foods. Although the $\mathrm{pH}$ of living fish is generally between 6.7 and 7.0, after death the $\mathrm{pH}$ value is lowered, then a gradual increase occur. For some fish, a $\mathrm{pH}$ value greater than 7.0 indicates spoilage (Woyewoda et al. 1986). The $\mathrm{pH}$ in fish tissues drops due to smoking, generally to 6.5 or less (Doe, 1998). The data reported in table (1) indicated that, the minimum, maximum and mean values of $\mathrm{pH}$ in packed and unpacked smoked herring fish were 5.80, 7.00, 6.27 \pm 0.05 and $5.81,7.25,6.30 \pm 0.06$ respectively, $96 \%, 84 \%$ of the samples accepted and $4 \%, 16 \%$ were rejected respectively according to (Egyptian standard of smoked fish 228/2005) which could be attributed to initial bacterial activity through the production of ammonia and other bases. Also the data reported in table (1) indicated that, the minimum, maximum and mean values of total volatile nitrogen in packed and unpa- 
cked smoked herring fish were 19, 32, 24.76 \pm 0.50 and 20, $38,27.02 \pm$ $0.73 \mathrm{mg} / 100 \mathrm{~g}$. respectively, $100 \%, 88 \%$ of the samples accepted respectively, while, $12 \%$ from unpacked samples were rejected according to (Egyptian standard of smoked fish 228/2005). Lower results were reported by (Cardinal et al. 2004). Sodium chloride enhances the flavor of foods and plays as a preservative as well as functional role in food processing. The mechanism of inhibition of microorganisms by sodium chloride is mainly by lowering the water activity of the substrate. Studies have also indicated that sodium chloride could have a role in interfering with substrate utilization in microorganisms (Ravishankar and Juneja 2000).

The findings recorded in table (1) declared that, the minimum, maximum and mean values of salt content in packed and unpacked smoked herring fish were $1.50,2.00,1.76 \pm 0.02$, and $1.52,2.90,1.80 \pm 0.40 \%$ respectively, $100 \%, 92 \%$ of the samples accepted respectively and $8 \%$ of unpacked smoked fish were rejected according to (Egyptian standard of smoked fish 228/2005) which may attributed to over use brine solution. On the other hand, the minimum, maximum and mean values of thiobarbituric acid in packed and unpacked smoked herring fish were $1.50,4.00,2.75 \pm 0.11$ and $2.00,5.00,3.40 \pm 0.11 \mathrm{mg} \mathrm{MD} / \mathrm{kg}$ respectively, $100 \%, 90 \%$ of the samples accepted respectively, and $10 \%$ of unpacked smoked fish were rejected according to (Egyptian standard of smoked fish 228/2005) which could attributed to breakdown of oxidation products, mainly malonaldehyde, during smoking due to the high temperature (Goktepe and Moody, 1998). (Beltran and Moral 1991) reported that high TBA values are correlated with the degree of oxidative rancidity of fats . Nearly similar results were obtained by (Da Silva ,2002). 
Fish can carry bacteria that can cause infection or intoxication in humans. These bacteria can either be a part of the indigenous flora or their presence is a result of contamination. The indigenous flora bacteria such as Listeria monocytogenes, Vibrio parahaemolyticus and Clostridium botulinum. Microbial contamination of smoked fish includs Staphylococcus aureus and Listeria monocytogenes and from the animal/human reservoir Salmonella and E. coli (Huss, 2003).

(Egyptian standard of smoked fish 228/2005) stipulated that smoked fish should be free from any visible mould growth and their toxins, Escherichia coli, Listeria monocytogenes, Vibrio parahaemolyticus, Clostridium botulinum, Saphylococcus aureus coagulase positive and Salmonella. Moreover total aerobic count, coliforms count and total anaerobic count should not exceed $10^{5}, 10$ and $10^{5} \mathrm{CFU} / \mathrm{g}$. respectively.

From the obtained results in (table,3) it is evident that, the incidence of positive samples appeared as minimum, maximum and mean values of total aerobic count of packed and unpacked smoked herring fish were 50 (100\%), $2 \times 10^{2}, 9 \times 10^{4}, 3.7 \times 10^{4} \pm 3.9 \times 10^{3}, 50(100 \%), 8 \times 10^{3}, 1.3 \times 10^{5}$ and $4.9 \times 10^{4} \pm 5.2 \times 10^{3} \mathrm{CFU} / \mathrm{g}$. respectively. Nearly similar results were reported by (Bastawrows et al. 2000), while higher results were recorded by (Besharati, 2004). The presented data reaveled increasing in count of unpacked samples than packed samples and according to (Egyptian standard of smoked fish 228/2005) all the examined samples of packed smoked herring fish were satisfied the standard and lied within the permissible limit (not exceeding $10^{5} \mathrm{CFU} / \mathrm{g}$, while 5 (10\%) of examined unpacked samples were rejected due to contamination with more than $10^{5} \mathrm{CFU} / \mathrm{g}$, which indicated cross contam-ination from different sources such as fresh fishes, salt used, human and animal wastes, inadequately 
cleaned equipment and exposure to unsuitable environmental conditions (Thatcher and Clark,1978). On the other hand, the incidence of positive samples, appeared as minimum, maximum and mean values of total anaerobic count of packed and unpacked smoked herring fish were 10 $(20 \%), 2 \times 10,1 \times 10^{2}, 6.3 \times 10 \pm 3.9,18(36 \%), 6 \times 10,5 \times 10^{2}$ and $1.3 \times$ $10^{2} \pm 1.5 \times 10 \mathrm{CFU} / \mathrm{g}$. respectively, (table, 3). These findings are in disagreement with those reported by (Sen and Tamelli, 2003), and when compared the aforementioned results with (Egyptian standard of smoked fish 228/2005) we found that, all the examined samples of packed smoked herring fish were satisfied the standard and lied within the permissible limit (not exceeding $10^{2} \mathrm{CFU} / \mathrm{g}$, whereas $6(12 \%)$ of unpacked samples were rejected due to exceeding $10^{2} \mathrm{CFU} / \mathrm{g}$, which may be attributed to poor handling and / or improper storage methods.

Also it is evident from (table 3 ) that, the incidence of positive samples appeared as minimum, maximum and mean values of total mould and yeast count of packed and unpacked smoked herring fish were $26(52 \%), 2 \times 10,1.9 \times 10^{2}, 1.04 \times 10^{2} \pm 7.9,32(64 \%), 3 \times 10,7 \times 10^{2}$ and $1.8 \times 10^{2} \pm 2.3 \mathrm{CFU} / \mathrm{g}$. respectively. The obtained results agreed with those reported by(Sen and Tamelli,2003).Smoked fish can be contaminated by mould mainly from contaminated smoke chamber and wood smoke as well as saw dust used in smoking of fish (Graikoski, 1973), while yeast may reach the product during processing, handling and distribution due to neglected hygienic measures. Contamination of smoked fish with the objectionable moulds and yeasts will produce undesirable change of fish rendering it unfit for marketing. It will also increase the risk of infection by many fungi of public health hazard which reflect the possibility of developing serious diseases to consumers (Edris, 1996). Furthermore, many 
strains of moulds are able to produce mycotoxins which possess carcinogenic properties (Goldblatt and Stolopf, 1983).

Also it is evident from (table 3 ) that, the incidence of positive samples appeared as minimum, maximum and mean values of total coliforms count of packed and unpacked smoked herring fish were $7(14 \%), 3,9$, $5.3 \pm 0.34,10(20 \%), 3,1.5 \times 10$ and $8 \pm 0.7 \mathrm{CFU} / \mathrm{g}$. respectively. Nearly similar results were recorded by (Besharati, 2004), and according to (Egyptian standard of smoked fish 228/2005) all the examined samples of packed smoked herring fish were satisfied the standard and lied within the permissible limit (not exceeding $10 \mathrm{CFU} / \mathrm{g}$, on the other hand, 10 (20\%) of examined unpacked samples were lied out of this limit (more than $10 \mathrm{CFU} / \mathrm{g}$ ), which may be attributed to inadequate sanitary conditions during preparation, handling and storage (ICMSF, 1978).

From table (3) it is apparent that, the incidence of positive samples appeared as minimum, maximum and mean values of total Bacillus cereus count of packed and unpacked smoked herring fish were 14 (28\%), 9x10, 2x 10 $30.5 \times 10^{2} \pm 7.5 \times 10,19(38 \%), 1.2 \times 10^{2}, 1 \times 10^{4}$ and $2.9 \times 10^{3} \pm 4.8 \times 10^{2} \mathrm{CFU} / \mathrm{g}$. respectively. Nearly similar findings were reported by (Bastawrows et al. 2000) while higher results were recorded by (Plaher et al. 1991). Bacillus cereus had been reviewed in food poisoning cases linked with packed fish (Schamitt et al. 1976). It was also implicated in two distinct forms of food poisoning, a rapid onset emetic syndrome and delayed onset diarrhoeal syndrome (Van Netten et al. 1990). However in the present study Bacillus cereus was found in such counts that may be considered innocuous since the minimum level required to cause illness had been estimated to be $>10^{5} \mathrm{CFU} / \mathrm{g}$. ( Hobbs, 1974). 
Data given in table (3) shows that, the incidence of positive samples appeared as minimum, maximum and mean values of total Staphylococcus aureus count of packed and unpacked smoked herring fish were 25 $(50 \%), 5 \times 10,9 \times 10^{2}, 3 \times 10^{2} \pm 3.5 \times 10,37(74 \%), 6 \times 10,1.1 \times 10^{3}$ and $4.7 \times 10^{2} \pm 4.2 \times 10 \mathrm{CFU} / \mathrm{g}$. respectively. Also the results recorded in table (4) point out that, Staphylococcus aureus coagulase positive could not be isolated from packed smoked herring fish samples, while isolated from 6 (12\%) of unpacked smoked herring fish samples. Nearly similar results were reported by (Sen and Tamelli, 2003).

According to (Egyptian standard of smoked fish 228/2005), all the examined samples of packed smoked herring fish were satisfied the standard and lied within the permissible limit ( free from Staphylococcus aureus coagulase positive), on the other hand, 6 (12\%) of examined unpacked samples were lied out of this limit.

The presence of Staphylococcus aureus in the examined samples suggests the poor handling and / or the improper storage methods given to such commodities. It is also a good indicator of the poor personal hygiene of food handlers where, the organism originate from a suppurating lesion or from the nostrils of a carrier(Elwi, 1994). Smoked fish being a commonly consumed product, can be considered as a potential cause of food poisoning (Dalmacio et al. 1988).

From other view, the achieved results revealed that, all the examined samples of packed and unpacked smoked herring fish were free from Escherichia coli, Vibrio Paraheamolyticus, Listeria monocytogenes, Salmonellae and Clostridium botulinum. 
This could be explained in the view that hot smoke process was sufficient to destroy these organisms. Nearly similar findings were reported by (Bastawrows et al. 2000, Da Silva 2002 and Sen and Tamelli, 2003).

The obtained results allow to conclude that, regarding the sensory evaluation only $2 \%$ of packed smoked herring fish samples were rejected due to macerated skin, friable consistency and musty flesh odor meanwhile, unpacked examined samples contained $14 \%$ rejected due to macerated skin, very macerated skin and friable consistency and $10 \%$ rejected due to musty flesh odor and salty flesh taste. Concerning the chemical examination, $4 \%$ of packed smoked herring fish samples were rejected due to over $\mathrm{pH}$ value, while $16 \%, 12 \%, 8 \%$ and $10 \%$ of unpacked smoked herring fish samples were rejected due to over $\mathrm{pH}$ value, TVN, salt content and thiobarbituric acid number respectively more than the accepted limits of the Egyptian standard. While microbiologically, all the samples of packed smoked herring fish lied within the limits Egyptian standard of smoked fish 228/2005, concerning unpacked samples $10 \%, 12 \%, 20 \%$ and $12 \%$ were rejected due to contamination with total aerobic bacterial count, total anaerobic bacterial count, total coliforms count and Staphylococcus aureus coagulase positive respectively more than the accepted limits of the previous standard. So we can depend upon sensory and chemical tests besides the microbiological examination on determination of hygienic status of smoked herring fish .Also the data indicated that we can not depend only on smoking process but must incasing the final product after smoking to minimize contamination with microorganisms. Finally strict hygienic measures should be taken during different stages of handling, transportation and storage. 
Table (1): Sensory examination of packed and unpacked smoked herring fish (50 of each).

\begin{tabular}{|c|c|c|c|c|c|}
\hline \multirow[t]{2}{*}{ Items } & \multirow[t]{2}{*}{ Characters } & \multicolumn{2}{|c|}{$\begin{array}{l}\text { packed smoked } \\
\text { herring fish }\end{array}$} & \multicolumn{2}{|c|}{$\begin{array}{l}\text { unpacked smoked } \\
\text { herring fish }\end{array}$} \\
\hline & & NO. & $\%$ & NO. & $\%$ \\
\hline \multirow{3}{*}{ Skin condition } & Intact & 449 & 98 & 444 & $\overline{88}$ \\
\hline & Macerated & 1 & 2 & 5 & 10 \\
\hline & Very macerated & 0 & 0 & 1 & 2 \\
\hline \multirow{4}{*}{ Skin color } & Golden brown & 5 & 10 & 3 & 6 \\
\hline & Golden yellow & 45 & 90 & 47 & 94 \\
\hline & Dark brown & 0 & 0 & 0 & 0 \\
\hline & \begin{tabular}{|l|} 
Mouldy growth \\
\end{tabular} & 0 & 0 & 0 & 0 \\
\hline \multirow{4}{*}{ Consistency } & Firm & 49 & 98 & 43 & 86 \\
\hline & Friable & 1 & 2 & 7 & 14 \\
\hline & Soft & 0 & 0 & 0 & 0 \\
\hline & Dry & 0 & 0 & 0 & 0 \\
\hline \multirow{2}{*}{ Flesh odor } & Smoked fishy flesh & 49 & 98 & 45 & 90 \\
\hline & Musty & 1 & 2 & 5 & 10 \\
\hline \multirow{4}{*}{ Flesh taste } & Smoked fishy flesh & 50 & 100 & 45 & 90 \\
\hline & Salty & 0 & 0 & 5 & 10 \\
\hline & Musty & 0 & 0 & 0 & 0 \\
\hline & Bitter & 0 & 0 & 0 & 0 \\
\hline
\end{tabular}

Table (2): Statistical analytical results of chemical examination of packed and unpacked smoked herring fish (50 of each).

\begin{tabular}{|c|c|c|c|c|}
\hline Items & Accepted limit & Characters & $\begin{array}{c}\text { packed } \\
\text { smoked } \\
\text { herring fish }\end{array}$ & $\begin{array}{l}\text { unpacked } \\
\text { smoked } \\
\text { herring fish }\end{array}$ \\
\hline \multirow{5}{*}{$\mathrm{pH}$} & \multirow{5}{*}{ Less than 6.8} & Min. & 5.80 & 5.81 \\
\hline & & Max. & 7.00 & 7.25 \\
\hline & & Mean+SE & $6.27+0.05$ & $6.30+0.06$ \\
\hline & & Accepted & $96 \%$ & $84 \%$ \\
\hline & & Rejected & $4 \%$ & $16 \%$ \\
\hline \multirow{5}{*}{ TVN } & \multirow{5}{*}{$\begin{array}{l}\text { Less than } 35 \mathrm{mg} / \\
100 \mathrm{~g} .\end{array}$} & Min. & 19 & 20 \\
\hline & & Max. & 32 & 38 \\
\hline & & Mean+SE & $24.76+0.50$ & $27.02+0.73$ \\
\hline & & Accepted & $100 \%$ & $8 \overline{8 \%}$ \\
\hline & & Rejected & $0 \%$ & $12 \%$ \\
\hline \multirow{5}{*}{ Salt } & \multirow{5}{*}{ Not more than $2 \%$} & Min. & 1.50 & 1.52 \\
\hline & & Max. & 2.00 & 2.90 \\
\hline & & Mean+SE & $1.76 \pm 0.02$ & $1.80 \pm 0.40$ \\
\hline & & Accepted & $100 \%$ & $92 \%$ \\
\hline & & Rejected & $0 \%$ & $8 \%$ \\
\hline \multirow{5}{*}{$\begin{array}{l}\text { Thiobarbituric acid } \\
\text { reactive substances }\end{array}$} & \multirow{5}{*}{$\begin{array}{l}\text { Not more than } \\
4.5 \mathrm{mg} \\
\text { malonaldehyde/kg }\end{array}$} & Min. & 1.50 & 2 \\
\hline & & Max. & 4.00 & 5.0 \\
\hline & & Mean \pm SE & $2.75 \pm 0.11$ & $3.40 \pm 0.11$ \\
\hline & & Accepted & $100 \%$ & $90 \%$ \\
\hline & & Rejected & $0 \%$ & $10 \%$ \\
\hline
\end{tabular}

Kafrelsheikh Vet. Med. J. Vol. 7 No. 1 (2009) 
Table (4): Incidence of positive coagulase Staph.aureus in examined packed and unpacked smoked herring fish(50 of each).

\begin{tabular}{|c|c|c|c|c|}
\hline \multirow[t]{2}{*}{ Accepted limited } & \multicolumn{2}{|c|}{$\begin{array}{c}\text { packed } \\
\text { smoked herring }\end{array}$} & \multicolumn{2}{|c|}{$\begin{array}{c}\text { unpacked smoked } \\
\text { herring }\end{array}$} \\
\hline & \multicolumn{2}{|c|}{ Positive samples (Rejected) } & \multicolumn{2}{|c|}{ Positive samples (Rejected) } \\
\hline \multirow{2}{*}{ Negative } & NO. & $\%$ & NO. & $\%$ \\
\hline & 0 & 0 & 6 & 12 \\
\hline
\end{tabular}

\section{REFERENCES}

- American Public Health Association APHA (1992): Compendium of methods for the micribiological examination of foods $3^{\text {rd }}$ Ed. Washington, D. C. USA.

- Association of official analytical chemists AOAC (1990): Sodium chloride in seafood Official Methods of Analysis, $15^{\text {th }}$ Ed. Washington. Dc.

- Baily, W.R.and Scott,E. G.(1998):Diagnostic Microbiology. A Textbook for the isolation and identification of pathogenic Microorganisms. The C. V. Mosby Company Saint Louis.

- Bastaworows, A.F., Abo- El- Alla, A.A., Sayed, A. M. and Abd ElSatar, M. A.(2000): Microbiological quality of smoked herring fish in Assiut City. Assiut Vet. Med. J. Vol. 43 NO. 85, 110-123.

- Beltran, A. and Moral A. (1991): The effects of fat contents and storage temperature on the storage life of smoked sardine fillets (Sardina pilchadus W). Prepared from frozen sardine. Food Chemistry, 42 (3), $347-356$.

- Besharati, N. (2004): Preliminary observation on nutritional and microbiological changes of hot and cold smoked trout. United Nation Univ. Fisheries Training Programme. 
- Cardinal,M.; Gunnlaugsdottir, H.; Bjoernevik, M. and Quisse, A. (2004): Sensory characteristics of cold - smoked Atlantic salmon (Salmo salar) from European market and relationships with chemical, physical and microbiological measurements Food Research International 37 (2): 181-193.

- Conell, J. J. (1990): Control of fish quality $3^{\text {rd }}$ Ed., Blackwell Scientific Publications, Oxford. PP. 85-88, 97-103.

- Conell, J. J. (1995): Control of fish quality 4 rd Ed., Fishing News Books. Torry Research Station of U.K. Ministry of Agriculture.

- Dalmacio, I. F.; Guzma, P. P.; De-Guzman, p. p. and Delacruz, E. T. (1988): Occurrence of Staphylococcus aureus in some Philippine foods and its enterotoxins in smoked fish.

- Da Silva L.V.A. (2002): Hazard Analysis Critical Control Point (HACCP), Microbial Safety, and Shelf Life Of Smoked Blue Catfish (ICTALURUS FURCATUS) Master of Science Fac.of the Louisiana State University and Agricultural and Mechanical College

- Doe P.E., (1998): Fish Drying and Smoking Production and Quality. Technomic Publishing Co., Inc. Lancaster, Pennsylvania

- Edris, A. M. (1996): Microbial evaluation of some marketed smoked fish . Zagazig Vet . J . 24 (1) 76-81.

- Egyptian Organization of Standardization and Quality Control (288 / 2005): Egyptian standard of smoked fish.

- El- Kewaiey, I. A. (2001): Quality assessment of some locally manufactured and retailed meat and fish products Ph. D. Thesis, Fac. Vet. Med. Tanta Univ.

- Elwi, E. M. (1994): Sanitary importance of meat meals in Governometal hospitals in Assiut City. Ph. D. Thesis Fac. Vet. Med. Assiut Univ.

- FAO (1970): Food and Agriculture Organization of United Nation. Smoked curing of fish. Fisheries. Rep., 88, FAO, Rome, Italy. 
- FAO (1980): Food and Agriculture Organization of United Nation. Manual of Food Quality Control. 3-commodities.United Nations. Rome.

- FAO(1992): Food and Agriculture Organization of United Nation.Manual of Food Quality Control. United Nation Rome. 1- Microbilogical Analysis. Staphylococcus aureus counts.

- Finegold, S.M. \& JoBaron, E. (1986): Bailey and Scott's Diagnostic Microbiology. The C.V. Mosby Company. $7^{\text {th }}$ ed. 1986.

- Goktepe, I. and Moody, M.W. (1998): Effect of modified atmosphere package on the quality of smoked catfish. Journal of Muscle Foods, 9:375-389.

- Goldblatt, L. A. and Stoloff, L. (1983): History and natural occurrence of aflatoxins. Proc. Int. Symp . Mycotoxins. 33-64.

- Graikoski, J.T. (1973): Microbiology of cured and fermented fish in Chichester, C. O. and Graham, L.L.D. (Eds). Microbial safety of fishery products. Acad. Press. New York and London.

- Hobbs, G. (1974): Clostridium welchii and Bacillus cereus infection intoxication. Postgard Med., 50:597-601.

- Howgate, P.; Johnston, H. and Whittle, K. J. (1992): Multilingual guide to EC freshness grades for fishery products . Torry Research Station. Hberdeen . 32 pp.

- Huss, H. H. (2003): Assessment and management of seafood safety and quality . Food and Agriculture Organization of the United Nations : FAO Fisheries technical paper no. T444.

- International Commission of Microbiological Specifications for Foods ICMSF (1978): Microorganisms in Food. Their Significance and Examination. $2^{\text {nd }}$ Ed., Univ. Toronto, press Toronto and Buffalo Canada.

- International Commission of Microbiological Specifications for Foods ICMSF (1996): International Commission of Microbiological Specifications for Foods: Microorganisms in Food. Vol. 1 Their Significance and methods of enumeration $2^{\text {nd }} E d$., Univ. Toronto, press Toronto and Buffalo Canada. 
- International Organization for Standardization (ISO) (1979): International standard organization ISO- 2917, Meat and meat products: Measurement of PH (References method)

- International Organization for Standardization (ISO) (1994): Milk and milk products. Enumeration of Presumptive Escherichia coli. ISO / DIS, 11866.

- International Organization for Standardization(ISO)(1995): Horizontal method for the detection and enumeration of Listeria monocytogenes. ISO / DIS, 11290-1.

- Krasemann, $S$.(2004): A History of smoke preservation < http :// www. 3men.com/history.htm.

- Monica Cheesbrough(1984): Medical Laboratory Manual for tropical countries. Vol.II Microbiology. ELBS. Tropical Health Technology / Butter Worth.

- Olley, J. Doe, P. E. Heruvati, E. S. (1998): The influence of drying and smoking on the nutritional properties of fish In: Fish smoking and drying, Editor. Burt, J.R. pp. 1-11 London and New York: Elsevier applied science.

- Pikul, J.; Leszezynski, D. and Kummerow, F. (1983): Elimination of sample autoxidation by butylated hydroxyl toluene additions before thiobarbituric acid assay for malonaldehyde in fat from chicken meat J. Agric. Food Chem., (31): 1338.

- Plahar, W. A.; Pace, Rf. D. and Lu, J. Y. (1991): Effect of storage conditions on the quality of smoked dried herring ( Sardinella eba) J. Sci. Food \& Agric., 57 (4): 597-610.

- Ravishankar, S. Juneja V. K. ( 2000): Sodium chloride. In Natural Food Antimicrobial Systems. Edited by A. S. Naida. CRC Press LLC. N. W. Corporate Blvd. Boca Raton, Florida.

- Ruiter, A. (1995): Fish and fishery products: Composition, nutritive properties and stability. CAB International. 
- Schmitt,N.;Bower,E. J. and W illoughby, B. A. (1976): Food poisoning outbreak attributed to Bacillus cereus.J.of Public Health,67:418-422.

- Sen,M.K.C.and Temelli, S. (2003): Microbial and chemical qualities of marinated anchovy prepared with different vegetable additives and sauce. Revue Med. Vet. 154 (11): 703-707.

- Shewan, J. M. Macintoch, R. G.; Tucker, C. G. and Ehrenberg, A. S. C. (1953): The development of numerical scoring system for the sensory assessment of the spolage of wet white fish stored in ice. Journal of the science of food and agriculture 4, 283-298.

- Tarladgis, B.G.; Watts, B.M.; Younathan,M.T.and Dugan, L. R. (1960): Adistillation method for quantitative determination of malonaldehyde in rancid foods. J. Am. Oil Chem. Soc.; ( 37 ): 44.

- Thatcher, F. S. and Clarck, D. S. (1968): Microorganisms in food. Their significance and Methods of Enumeration. Tornto, Univ. of Toronto press.

- Thatcher, F. S. and Clarck, D. S. (1978): Microorganisms in food (ICMSF) $2^{\text {nd }}$ Ed. Academic Press. New York.

- Van Den Broek, M. J. M.; Mossel, D. A. and Mol, H. (1984): Microbiological quality of retail fresh fillets in the Netherlands Int. J. Food Microbiol.; 1:53.

- Van Netten, P.; Van de Moosdjk, A.; Van Hoesel, P.; Mossel, D. A. A. and Perales, I. (1990): Psychrotrophic strain of Bacillus cereus producing enterotoxin. J. Appl. Bacteriol., 69: 73-79.

- Wheaton, F. W. and Lawson, T. B. (1985): Processing aquatic food products . John Wiley and Sons New York .

- Woyewoda, A.D., Shaw, S.J., Ke, P.J., and Burns, B.G.(1986): Quality indices-lipid related.In Recommended Laboratory Methods for Assessment of Fish Quality. Canadian technical report of fisheries and aquatic science, Canada. 


\section{الحالة الصحية لأسماك الرنجة الملدخنة المباعة فى مدينة كفر الشيخ

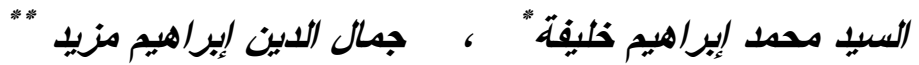

\section{معهز بحوث صحة الحيوان - المعمل الفرعى بكفر الثيخ" وحدة صحة الأغذية معهز بحوث صحة الحيوان - المعل الفرعى بكفر الثيخ" وحدة البكتيريولوجى}

تم تجميع عدد 100 عينة من اسماك الرنجة المدخنة المعروضة للبيع فى مدينة كفر الثيخ

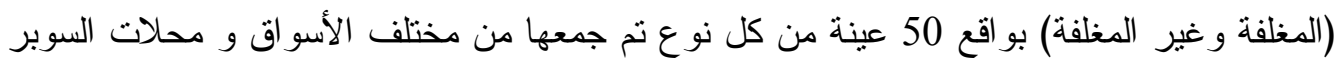

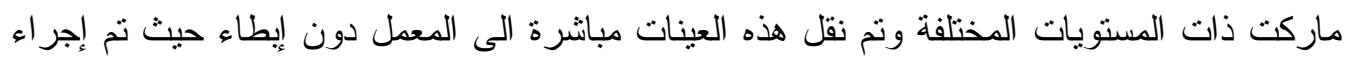
الاختبار ات المختلفة عليها ( الحسية ، الكيميائية و الميكروبيولوجية ) و أظهرت النئن النتائج الآتي:

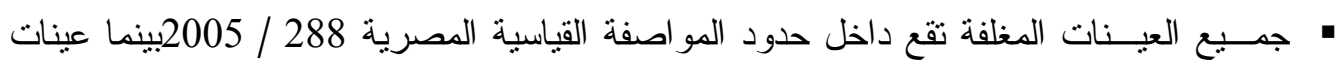
الــرنجة غير المغلفة تحنوى على عد كلى للميكروبات الهو ائية ، عد كلى للميكروبات اللاهو ائية

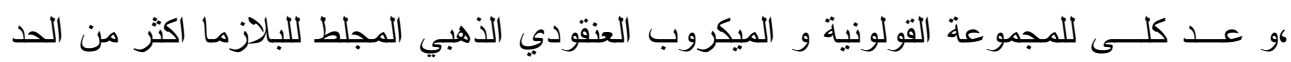
المسموح بنسب 10 \% ، 12 \% ، 20 \% و 12 \% \% ع على على النو الي . • بالنـسبة للتقييم الحسى وجد ان 2 \% من العينات المغلفة غير مطابقة نتيجة لتهنك الجلد و هشاثنة

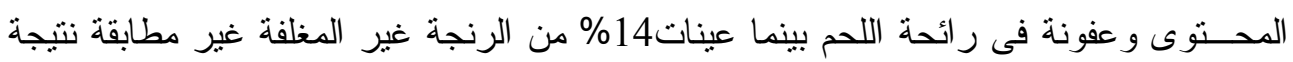

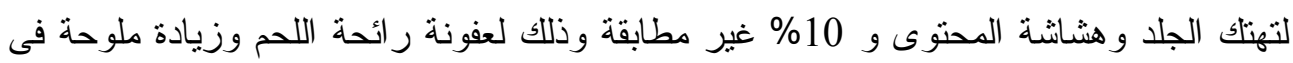
• طعم اللحم أما بالنسبة للفحوصات الكيميائية فقد وجد ان 4 \% من العينات المغلفة غير مطابقة لارتفاع قيمة

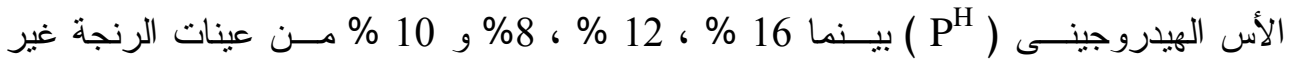
المغلفة غير مطابقة لارتفاع فى قيم الاس العيدروجينى ( (P) )، المركبات النيتروجينية الطيارة، المحتوى الملىى و حامض الثيوباربتيوريك على التو الى.

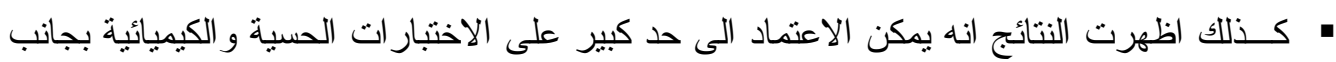

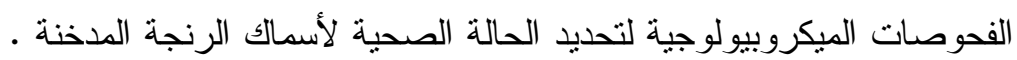

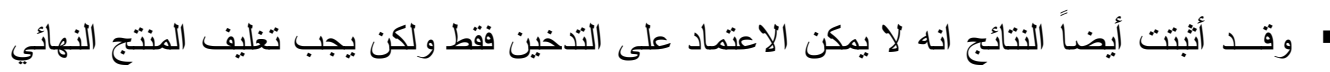

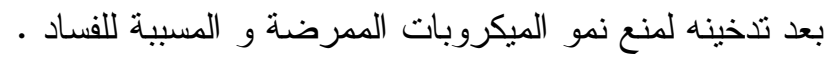
• وقد تم مناقتنة التوصيات اللازمة للحصول على منتج آمن وذات جودة عالية. 